\title{
. \\ Colonialism on Spatial Transformation: A Socio-Spatial Analysis of the Outdoor Transitional Spaces of Sri Lankan House ${ }^{\dagger}$
}

\author{
Deepthie Perera (D)
}

\section{check for}

updates

Citation: Perera, D. Colonialism on Spatial Transformation: A Socio-Spatial Analysis of the Outdoor Transitional Spaces of Sri Lankan House. Environ. Sci. Proc. 2021, 12, 1. https://doi.org/10.3390/ environsciproc2021012001

Academic Editor: Luciano Cardellicchio

Published: 2 December 2021

Publisher's Note: MDPI stays neutral with regard to jurisdictional claims in published maps and institutional affiliations.

Copyright: (C) 2021 by the author. Licensee MDPI, Basel, Switzerland. This article is an open access article distributed under the terms and conditions of the Creative Commons Attribution (CC BY) license (https:// creativecommons.org/licenses/by/ $4.0 /)$.
School of Built Environment, Kensington Campus, University of New South Wales Sydney, High Street, Kensington, NSW 2052, Australia; d.perera@student.unsw.edu.au or d.perera@unsw.edu.au; Tel.: +94-76-8635233 + Presented at the 3rd Built Environment Research Forum, Sydney, Australia, 1 December 2021.

\begin{abstract}
Sri Lanka, under the British from the early 19th century to 1948, saw a rapid growth in urban areas and the emergence of metropolitan bourgeoisie. Increasing demand for housing was met through housing schemes and private houses on smaller plots. Previous colonials, the Portuguese and the Dutch, adapted and continued the traditional house forms where outdoor transitional spaces such as verandas and courtyards remained as an integral part responding to climate and socio-cultural needs. However, the British period saw the advent of two noteworthy types of housing-a smaller re-adapted traditional house and an imported version of an all-enclosed house. This study evaluates the shift in socio-spatial role of the outdoor transitional spaces of single-unit houses from pre-colonial time up to independence using graphical analysis of the plan form combined with interviews on use of space.
\end{abstract}

Keywords: colonialism; outdoor transitional spaces; socio-spatial analysis; Sri Lanka; urban house

\section{Introduction}

Paul Oliver's extensive studies on vernacular architecture and Rapoport's research on environmental behaviour studies highlight that the social structure, traditions, and daily lives of a particular culture are represented in its arrangement of the domestic space, housing forms and settlement patterns [1-3]. This research takes it further by arguing that the above socio-cultural differences are embodied in outdoor transitional spaces of houses in countries and regions where they are widely used. In Sri Lankan pre-colonial house, outdoor transitional spaces such as verandas and courtyards played a major role in spatial organization (zoning), movement patterns, creating thresholds and as a space for living and social interaction [4,5]. This supported the premise brought forward by architectural historians that traditional Sri Lankan people lived around the house and not in the house (Nimal de Silva, personal interview, 18 January 2021).

\section{Materials, Methods and Results}

Urban areas started developing in Sri Lanka under the colonial rule starting from Portuguese in early 16th century. It was carried forward by the Dutch from the mid17 th century and a rapid growth was witnessed in urban areas under the British rule from early 19th century until 1948. The last period saw the emergence of a new social class, the metropolitan bourgeoisie. There was an increasing demand for housing for this group which was met through housing schemes and private houses on smaller plots. The preferred house type was single-unit and detached. Previous colonials, the Portuguese and the Dutch, adapted and continued the traditional house forms where outdoor transitional spaces remained as an integral part responding to climate and socio-cultural needs. The British period saw the advent of two noteworthy types of housing; a smaller re-adapted traditional house to fit on a reduced plot size and an imported version of a practical, all-enclosed house suitable for European living patterns called the PWD (Public Works 
Department) house [6] (p. 122). This study evaluates the shift in socio-spatial role of the outdoor transitional spaces from pre-colonial to independence, through graphical analysis of the plan form combined with interviews on use of space. Space Syntax methods are used to generate J-Graphs to evaluate the spaces in terms of zoning, movement patterns, spatial hierarchy, connectivity, and topology of space $[7,8]$.

Investigations revealed the following:

1. Outdoor transitional spaces played a major role as thresholds and contributed to spatial hierarchy and zoning in pre-colonial and colonial influenced traditional house forms.

2. Semi-outdoor living spaces are mostly on rings making people pass through them. They have high connectivity and are well used, generating social interaction within the house as well as with the neighbourhoods.

3. Imported house types did not have any liveable semi-outdoor spaces thus, offering new living patterns. Introduction of dead-end outdoor transitional spaces with no designated activity is also noted here.

\section{Conclusions}

It is true that the social structure changed with the emergence of new social groups affecting the living styles to a certain extent. The colonial presence influenced traditional house types so that they had layouts which reflected Western prototypes with the addition of semi-outdoor living spaces. Imported house types which became popular during British period with no semi-outdoor living areas did not provide the space to follow the existing socio-cultural norms of the country. The initial premise that Sri Lankan people live around the house is not represented there. Nevertheless, these colonial layouts were accepted and celebrated by the locals as popular urban typologies. The new social group subsequently adapted their living styles to suit the house rather than the house reflecting the living patterns. It became a symbol to identify with the Western-influenced group of bourgeoisies at that time. However, the question remains about the way forward for Sri Lankan urban house, and that will be explored through further research.

Funding: This research was funded by AUSTRALIAN GOVERNMENT RESEARCH TRAINING PROGRAM SCHOLARSHIP RTP Stipend (RSAP1000), CHESSN: 9251285933.

Institutional Review Board Statement: The study was conducted according to the guidelines of the HREA Panel E: Built Environment and approved by the Institutional Ethics Committee of UNIVERSITY OF NEW SOUTH WALES (Low Risk Ethics Approval—HC190583, 20th August 2019).

Informed Consent Statement: Informed consent was obtained from all subjects involved in the study.

Conflicts of Interest: The author declares no conflict of interest. The funders had no role in the design of the study; in the collection, analyses, or interpretation of data; in the writing of the manuscript, or in the decision to publish the results.

\section{References}

1. Oliver, P. Dwellings: The Vernacular House Worldwide, 2nd ed.; Phaidon Press Limited: London, UK, 2003.

2. Rapoport, A. House Form and Culture; Prentice-Hall, Inc: Hoboken, NJ, USA, 1969.

3. Rapoport, A. Culture, Architecture and Design; Locke Science Publishing Company, Inc.: Chicago, IL, USA, 2005.

4. de Silva, N. The Sri Lankan Tradition for Shelter. Sri Lanka Archit. 1990, 100, 2-11.

5. Perera, A. Traditional Court-yard houses in Matale District. In Historic Matale; Editorial Board of Historic Matale, Ed.; Matale Book Publication Board: Matale, Sri Lanka, 1996; pp. 67-96.

6. Pieris, A. Architecture and Nationalism in Sri Lanka: The Trouser under the Cloth; Routledge: Oxon, UK, 2013.

7. Hillier, B.; Hanson, J. The Social Logic of Space; University of Cambridge: Cambridge, UK, 1984.

8. Hillier, B. Space Is the Machine: A Configurational Theory of Architecture; Space Syntax: London, UK, 2007. 